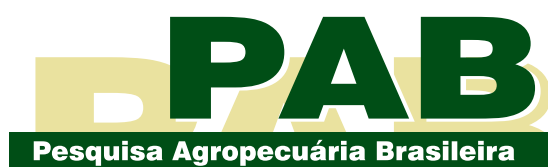

ISSN 1678-3921

Journal homepage: www.embrapa.br/pab

For manuscript submission and journal contents, access: www.scielo.br/pab

\title{
Phenological behavior of feijoa accessions in their main diversity center
}

\begin{abstract}
The objective of this work was to identify the minimum base temperature $(\mathrm{Tb})$ and the maximum base temperature $(\mathrm{TB})$ to predict the thermal time for six phenological stages of feijoa (Acca sellowiana) accessions. During ten noncontinuous harvests (2004 to 2017), 247 feijoa accessions, maintained in the Feijoa Active Germplasm Bank, in São Joaquim, in the state of Santa Catarina, Brazil, had their data recorded for: initial sprouting (IS), initial flowering (IF), end of flowering (EF), beginning of harvest (BH), and end of harvest (EH). Tb and TB were estimated by the Arnold's method of least variability, and the TT requirements were obtained by Ometto's method. $\mathrm{Tb}$ at $7.76^{\circ} \mathrm{C}$ and $\mathrm{TB}$ at $17.0^{\circ} \mathrm{C}$ were necessary when feijoa plants started growing (IS stage) just after winter; and $\mathrm{Tb}$ at $10.6^{\circ} \mathrm{C}$ and $\mathrm{TB}$ at $19.5^{\circ} \mathrm{C}$ were the calculated values from IS until BH. The budding stage of the accessions began in the mid-September (50.6\%); flowering occurred predominantly in November (90\%); and harvest began in March and lasted until May. About 176 days, with 1,014.4 growing degree-days, are necessary to complete the productive cycle from IS until BH. The early, intermediary, and late fruitripening accessions show different thermal time requirements.
\end{abstract}

Index terms: Acca sellowiana, base temperature, growing degree-days, pineapple guava, thermal time.

\section{Comportamento fenológico de acessos de feijoa em seu principal centro de diversidade}

Resumo - O objetivo deste trabalho foi identificar a temperatura base mínima $(\mathrm{Tb})$ e a temperatura base máxima (TB), para predizer o requerimento térmico de seis estágios fenológicos de acessos de feijoa (Acca sellowiana). Durante dez safras não sequenciais (2004 a 2017), 247 acessos, mantidos no Banco Ativo de Germoplasma, em São Joaquim, no estado de Santa Catarina, Brasil, tiveram seus dados registrados quanto a: início de brotação (IB), início de floração (IF), fim de floração (FF), início de colheita (IC) e fim de colheita (FC). A Tb e a TB foram estimadas pelo método de mínima variabilidade de Arnold, e os requerimentos térmicos foram obtidos pelo método de Ometto. Os valores de $\mathrm{Tb}$ a $7,76^{\circ} \mathrm{C}$ e $\mathrm{TB}$ a $17,0^{\circ} \mathrm{C}$ foram necessários quando as plantas de feijoa começaram a crescer (estágio IB), logo após o inverno; e Tb a $10,6^{\circ} \mathrm{C}$ e TB a $19,5^{\circ} \mathrm{C}$ foram os valores calculados de IB até IC. A brotação dos acessos iniciou-se em meados de setembro (50,6\%); a floração ocorreu predominantemente em novembro $(90 \%)$; e a colheita iniciou-se em março, tendo-se estendido até maio. São necessários cerca de 176 dias, com 1.014,4 graus-dia, para completar o ciclo produtivo desde IB até IC. Os acessos de feijoa de maturação precoce, intermediária e tardia apresentam diferentes exigências de requerimento térmico.

Termos para indexação: Acca sellowiana, temperatura base, graus-dia de desenvolvimento, goiabeira-serrana, soma térmica. 


\section{Introduction}

Feijoa [Acca sellowiana (O. Berg) Burret], also known as pineapple guava, is a species of the Myrtaceae family native to Southern Brazil and Uruguay. The Feijoa Active Germplasm Bank (AGBFeijoa), located in the municipality of São Joaquim, in the state of Santa Catarina, Brazil, presents a noticeable phenological variability of the accessions that is not yet properly characterized. Previously, the physicochemical fruit traits (Sánchez-Mora et al., 2019) and the genetic diversity (Saifert et al., 2020) of the AGB-Feijoa accessions were characterized. However, there are few studies on the feijoa phenology in Brazil, and the base temperature for each of this species phenological stages is not yet known.

The phenological stages of feijoa flowering were defined and characterized by a scale of letters (A$\mathrm{H})$ that favored the identification of the beginning of sprouting, beginning of flowering, and end of flowering (Ducroquet \& Hickel, 1991). The beginning and end of ripe stages were also evaluated to know the precocity characteristics of feijoa accessions (Ducroquet et al., 2000, 2007, 2008). The study of the phenological calendar also made it possible to predict the phenological times of any genotype, and thus the estimation of the number of days required for each event, and to design the management practices for the improvement of the crop productivity. This method has been used in studies with fruit trees for the prediction of phenophases: feijoa (Ducroquet \& Hickel, 1991); cactus pear (Segantini et al., 2010); green figs (Campagnolo et al., 2010), and apples (Lopes et al., 2012), among others.

The commercial cultivars of feijoa require different times to reach fruit maturation. The Alcântara cultivar reaches its fruit maturation at the beginning of March and ends 3 to 4 weeks later, and is assigned as precocious. By contrast, Nonante and Helena cultivars are classified as being of late maturing, since they begin to ripe about the second ten-day period of April, ending at the beginning of May. The Mattos cultivar has an intermediate ripening behavior between those of Alcântara and Helena cultivars (Ducroquet et al., 2007, 2008).

According to Segantini et al. (2010), the phenological behavior of the different species depends on the genetic, edaphoclimatic and cropping factors. Each species exhibits different reactions when subjected to distinct environment conditions. The development of different phenological events or stages of growth of a plant species is controlled by a strong interaction between genetics and environmental conditions, especially temperature (Chaves et al., 2017). The metabolic reactions in plants are mainly regulated by temperature, interfering with their development, that is, in the phenological phases (Segantini et al., 2014).

Using a base temperature in the different phenological stages of a plant, it is possible to estimate the thermal time. Each plant species has a base temperature for different phenological phases, or a single value that can be adopted for the entire crop cycle (Pezzopane et al., 2008). Plants develop as they accumulate thermal units above a base temperature, while, below this temperature, the plant paralyzes its development (Brunini et al., 1976; Miranda \& Campelo Júnior, 2010). The thermal accumulation, also known as degree-day, is defined as "the amount of heat effectively accumulated during the day and favorable to the growth of the vegetable", if the total of degreedays is achieved by subtracting the base temperature of the vegetable, from the average daily temperature (Brunini et al., 1976).

The growing degree-days (GDD) concept allows of the identification of the cycle duration and its different phases; therefore, degree-days become an important tool for planning pruning and adjusting the harvest season (Segantini et al., 2014). Excellent correlations were achieved by the use of the thermal time, for the duration of the crop cycle or for stages of the phenological development of a given cultivar.

The objective of this work was to identify the minimum base temperature and maximum base temperature, to predict the thermal time for six different phenological stages of feijoa accessions.

\section{Materials and Methods}

The study of phenology was carried out on accessions of the Feijoa Active Germplasm Bank (AGB-Feijoa), located at the experimental station of Empresa de Pesquisa Agropecuária e Extensão Rural de Santa Catarina (Epagri) (28¹6'40"S, 49 $56^{\prime} 09^{\prime \prime} \mathrm{W}$, at 1,400 m altitude), in the municipality of São Joaquim, in the state of Santa Catarina, Brazil.

Currently, the orchard is composed of 345 accessions, each one with up to three cloned plants, spaced at $3 \mathrm{~m}$ 
between plants and $5 \mathrm{~m}$ between rows. The evaluation was performed for 247 feijoa accessions, between 12 and 20 years of age. These accessions began to be introduced in the year 1992 in the AGB-Feijoa, and most clones originated in Planalto Sul region of Santa Catarina state (Ducroquet \& Ribeiro, 1996).

The weather data to characterize the feijoa phenology were obtained from the automated weather stations of Epagri, distant $200 \mathrm{~m}$ from the AGB-Feijoa ( $28^{\circ} 16^{\prime} 31^{\prime \prime} \mathrm{S}, 49^{\circ} 56^{\prime} 03^{\prime \prime} \mathrm{W}$, at $1,346 \mathrm{~m}$ altitude), and monitored by the Centro de Informações de Recursos Ambientais e de Hidrometeorologia de Santa Catarina (Ciram, 2020). Climatic daily data of the years referring to the phenological cycles of feijoa (2004-2017) were used to determine the base temperatures and degree-days required by plants. Phenological traits of 247 AGB-Feijoa accessions were measured during ten noncontinuous years $(2004 / 2005,2005 / 2006$, 2006/2007, 2007/2008, 2008/2009, 2009/2010, 2010/2011, 2011/2012, 2015/2016, and 2016/2017). The evaluations were carried out from September to December of each year, by recording weekly data of the phenological phases of the accessions.

In order to determine the phenological stages of the plants, visual observations per week were performed based on the scale proposed by Ducroquet et al. (2000): initial sprouting (IS), when $30 \%$ shoots were in stage C (evaluated in 2004/2005, 2005/2006, 2007/2008, 2008/2009, 2009/2010, and 2010/2011 seasons); initial flowering (IF), when $10 \%$ open flowers were in F3 stage (evaluated in 2004/2005, 2005/2006, 2006/2007, 2007/2008, 2008/2009, 2009/2010, 2010/2011, $2011 / 2012$, and $2015 / 2016$ seasons); end of flowering (EF), when $90 \%$ of flowers had fallen - stage $\mathrm{H}$ (evaluated in 2007/2008, 2008/2009, 2010/2011, 2015/2016, and 2016/2017 seasons); beginning of harvest $(\mathrm{BH})$, when fruit were ripe (evaluated in 2007/2008, 2008/2009, 2010/2011, and 2015/2016 seasons); and end of harvest (EH), when there were no more marketable fruit in the plant (evaluated in 2007/2008, 2008/2009, 2010/2011, and 2016/2017 seasons).

The minimum base temperature $(\mathrm{Tb})$ and maximum base temperature (TB) for six key phenological stages of feijoa were estimated from IS-IF, IF-EF, EF-BH, BH-EH, IS-BH, and IS-EH. The method of least variability (Arnold, 1959) was used to determine the base temperatures. This method consists in first determining the thermal sum of the differences between the average temperature during the considered period and the tested base temperatures. In the present study, to estimate the $\mathrm{Tb}$, a range of temperatures from 6 to $14^{\circ} \mathrm{C}$ was considered for different stages. Subsequently, the standard deviation in degree-days (Sdd) was determined, and the base temperature showed the lowest-standard deviation $(\mathrm{Sd})$ in days, calculated with the equation $\mathrm{Sd}=\mathrm{Sdd}$ / $(\mathrm{Tm}-\mathrm{Tb})$, in which: $\mathrm{Sd}$ is the standard deviation in days, for the series of stages considered; Sdd is the standard deviation in degree-days, for the whole series of accessions; Tm is the average temperature for the whole series of stages; and, $\mathrm{Tb}$ are the base temperatures tested. The lowest value of the standard deviation of the thermal sum, expressed in days, is the minimum base temperature of the plant. The TB was estimated in the same way as $\mathrm{Tb}$, but using the maximum temperatures and a range of temperatures from 8 to $20^{\circ} \mathrm{C}$ for different stages.

Using a second-degree regression model allowed of the determination of the optimum temperature for each phenological stage, in agreement with previous work (Salazar-Gutierrez et al., 2013; Parra-Coronado et al., 2015b). The statistical analyses were performed using the software R (R Core Team, 2017).

The thermal requirements of feijoa accessions were determined according to Ometto (1981) using the five conditions as follows: case 1 , if $\mathrm{TB}>\mathrm{TM}>\mathrm{Tm}>\mathrm{Tb}$, GDD $=[(\mathrm{TM}-\mathrm{Tm}) / 2]+(\mathrm{Tm}-\mathrm{Tb})$; case 2 , if $\mathrm{TB}>\mathrm{TM}>\mathrm{Tb}>\mathrm{Tm}, \mathrm{GDD}=\left[(\mathrm{TM}-\mathrm{Tb})^{2}\right] / 2(\mathrm{TM}-\mathrm{Tm})$; case 3, if $\mathrm{TB}>\mathrm{Tb}>\mathrm{TM}>\mathrm{Tm}, \mathrm{GDD}=0$; case 4 , if $\mathrm{TM}>\mathrm{TB}>\mathrm{Tm}>\mathrm{Tb}, \mathrm{GDD}=\{2[(\mathrm{TM}-\mathrm{Tm}) \times(\mathrm{Tm}-\mathrm{Tb})]$ $\left.+(\mathrm{TM}-\mathrm{Tm})^{2}-(\mathrm{TM}-\mathrm{TB})\right\} / 2(\mathrm{TM}-\mathrm{Tm})$; case 5 , if $\mathrm{TM}>\mathrm{TB}>\mathrm{Tb}>\mathrm{Tm}, \mathrm{GDD}=1 / 2\left\{\left[(\mathrm{TM}-\mathrm{Tb})^{2}-(\mathrm{TM}-\right.\right.$ $\left.\left.\mathrm{TB})^{2}\right] /(\mathrm{TM}-\mathrm{Tm})\right\}$, in which $\left({ }^{\circ} \mathrm{C}\right)$ : $\mathrm{TB}$ is the maximum base temperature; $\mathrm{TM}$ is the maximum daily temperature; $\mathrm{Tm}$ is the minimum daily temperature; and $\mathrm{Tb}$ is the minimum base temperature.

The thermal requirements of feijoa accessions were verified by groups, and classified as being of early, intermediary, and late ripe by applying the same criteria used for commercial cultivars of Santa Catarina, Brazil. Then, in the present work, early accessions begin their maturity until March $18^{\text {th }}$; intermediary accessions, from March $19^{\text {th }}$ until April $07^{\text {th }}$; and late accessions, from April $08^{\text {th }}$ until the beginning of May. 


\section{Results and discussion}

The phenological analysis of the data showed that, on average, the beginning of the budding of the AGB-Feijoa accessions begins in the middle of September, extending until the end of October (day 25 ). It was also verified that $50.6 \%$ of the accessions sprout in September, and the rest, in October (Figure 1). The results of the present study corroborates those by Ducroquet et al. (2000), performed in the same region, who found that the beginning of sprouting occurred in the middle of September, when plants showed new apical releases. Flowering in early accessions takes place in October (8.5\%), continuing in November for most the studied accessions (91.5\%).

In the present work, the harvest started in March, for a great number of the 247 evaluated accessions (54\%); while others ripened in April (42.6\%), and a small proportion of accessions, in May (3.4\%) (Figure 1). Previous studies with contrasting genotypes showed

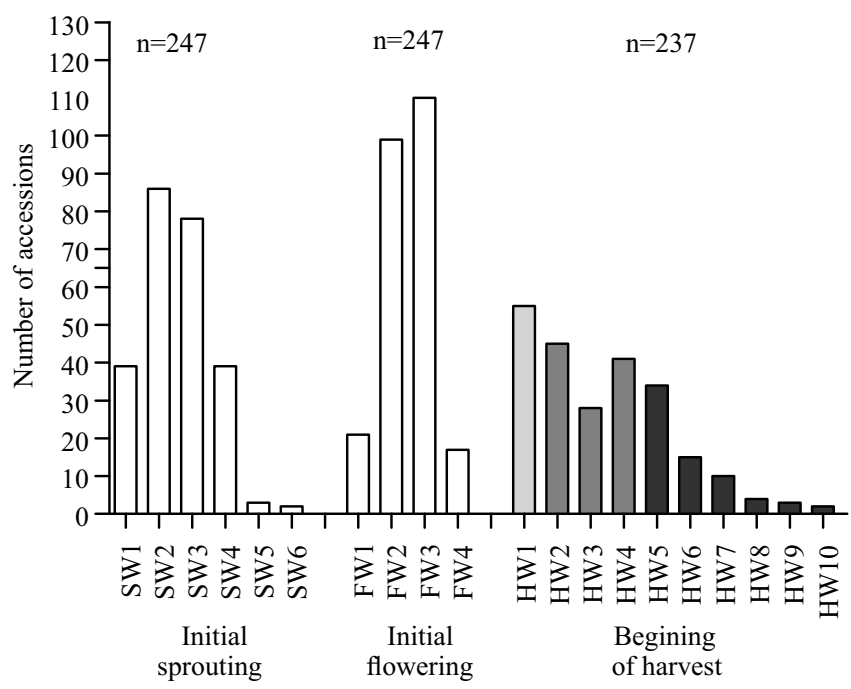

Figure 1. Phenological behavior of 247 feijoa (Acca sellowiana) accessions in the Active Germplasm Bank, in the municipality of São Joaquim, in the state of Santa Catarina, Brazil. SW1-SW6, six weeks of sprouting, from September 14 through October 28; FW1-FW4, four weeks of flowering, from October 25 through November 21; HW1HW10, 10 weeks of fruit harvest, from March 12 through May 25. For the harvest phenological stage, the light grey bars represent the accessions with fruit of early maturity; dark grey bars, fruit of intermediary maturity; and dark bars, fruit of late maturity. that the length of fruit ripeness season in Southern Brazil extends from the end of February until the beginning of June, and last for about 3 to 4 weeks in most accessions (three genotypes tested); however, the late accessions may face frost problems (Ducroquet \& Hickel, 1991).

The values of base temperature for each phenological stage of feijoa accessions, were: $\mathrm{Tb}=7.76^{\circ} \mathrm{C}$ and $\mathrm{TB}=17.0^{\circ} \mathrm{C}$, for the initial sprouting stage (IS-IF); $\mathrm{Tb}=7.92^{\circ} \mathrm{C}$ and $\mathrm{TB}=20.0^{\circ} \mathrm{C}$, for the initial flowering stage (IF-EF); $\mathrm{Tb}=12.3^{\circ} \mathrm{C}$ and $\mathrm{TB}=20.0^{\circ} \mathrm{C}$, from the end of flowering to the beginning of harvest (EF$\mathrm{BH}) ; \mathrm{Tb}=9.95^{\circ} \mathrm{C}$ and $\mathrm{TB}=16.5^{\circ} \mathrm{C}$, for the harvest stage; $\mathrm{Tb}=10.6^{\circ} \mathrm{C}$ and $\mathrm{TB}=19.5^{\circ} \mathrm{C}$, from sprouting until the beginning of harvest (IS-BH), and $\mathrm{Tb}=10.7^{\circ} \mathrm{C}$ and $\mathrm{TB}=19.5^{\circ} \mathrm{C}$, from sprouting until the end of harvest (IS$\mathrm{EH}$ ) (Figures 2 and 3). The values of base temperature found for feijoa cultivated plants in these phenological stages, in the municipality of São Joaquim, in the state of Santa Catarina, Brazil, are superior to those found for the tropical conditions (Andean region) in Colombia, which were $2.9^{\circ} \mathrm{C}, 3.0^{\circ} \mathrm{C}$, and $1.7^{\circ} \mathrm{C}$ for the flower bud to flowering, flowering to fruit setting, and flower bud to fruit harvest stages, respectively (ParraCoronado et al., 2015a). These results can facilitate the identification of suitable areas to growth distinct feijoa cultivars. In addition, the results achieved for $\mathrm{Tb}$ and TB will help to perform future bioassays regarding pruning tests.

In the sprouting and flowering stages, the base temperatures did not show many differences between them (7.8 and $7.9^{\circ} \mathrm{C}$, respectively). Small differences between the values of base temperatures to sprouting stages $\left(2.89^{\circ} \mathrm{C}\right)$ and flowering-fructification $\left(3.04^{\circ} \mathrm{C}\right)$ were also found for feijoa cultivated in Colombia (Parra-Coronado et al., 2015b). However, there is a difference between the phenological stages from sprouting until harvest, in both two growth regions. In the Andean region, feijoa plants constantly accumulate hours of cold, thus, they are always sprouting, flowering and producing fruit. This fact has no similarity with the orchards that grow in regions of temperate or subtropical climates, where the plants wait for the winter to accumulate hours of cold to restart the sprouting, flowering, and fruit production.

From the initial sprouting to the harvest of the 247 accessions, feijoa fruit took 35 days for the initial sprouting period, with 15 to 65 days amplitude. The flowering demanded 29 days on average, with 
variation from 10 to 69 days; the stage from the end of flowering to the beginning of harvest, took 115 days; and the stage from the beginning to the end of harvest took 34 days (Table 1). The flowering process is quite
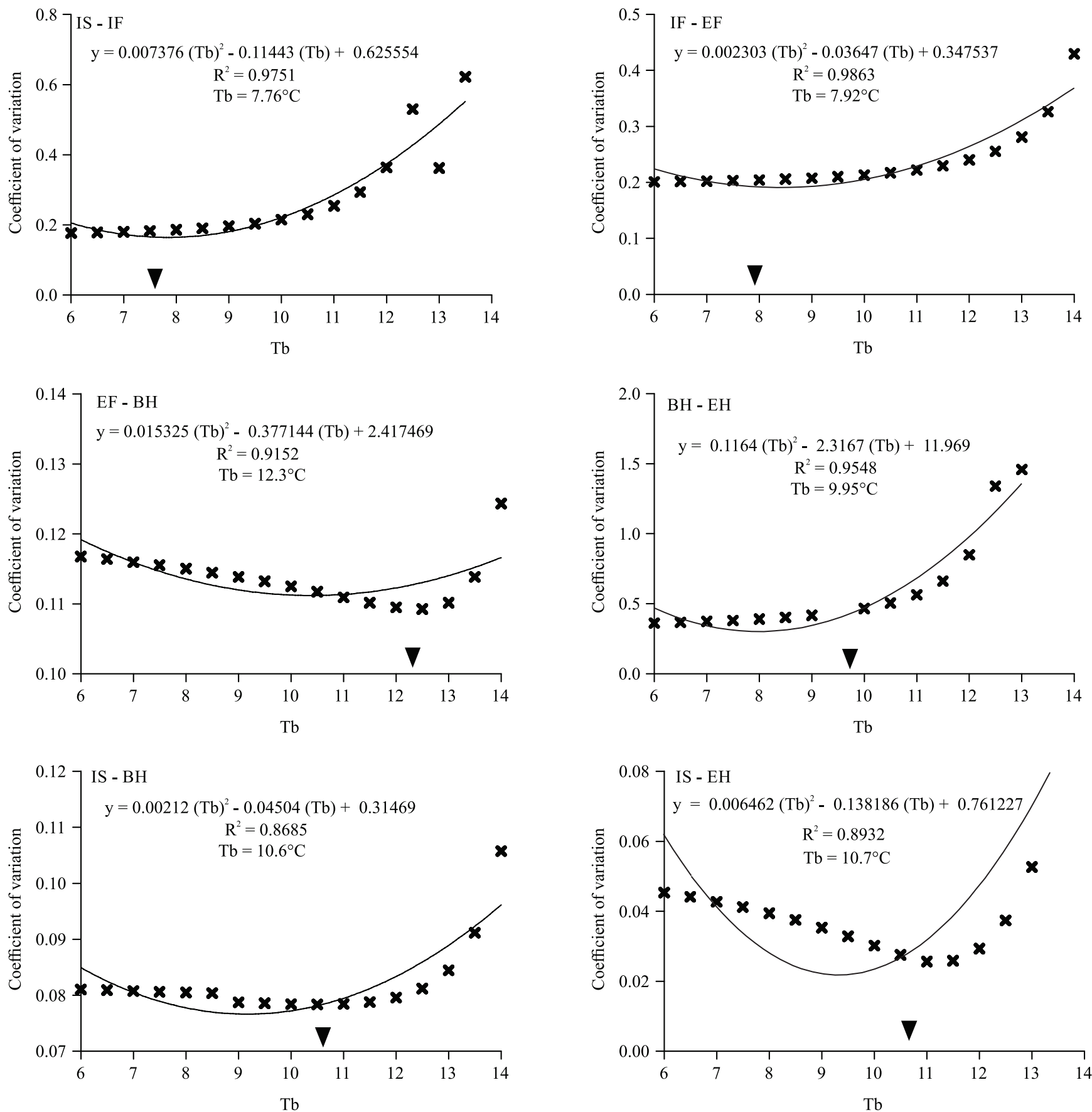

Figure 2. Minimum base temperature $(\mathrm{Tb})$ of six phenological stages of feijoa (Acca sellowiana) accessions by the method of lower variability (Arnold, 1959): A, from initial sprouting (IS) to initial flowering (IF); B, from IF to the end of flowering (EF); C, from $\mathrm{EF}$ to the beginning of harvest $(\mathrm{BH})$; $\mathrm{D}$, from $\mathrm{BH}$ to the end of harvest (EH); $\mathrm{E}$, from IS to $\mathrm{BH}$; and $\mathrm{F}$, from IS to EH. The evaluated feijoa accessions are maintained by the Active Germplasm Bank, in the municipality of São Joaquim, in the state of Santa Catarina, Brazil. Arrows point to Tb values. 
uneven, since occurs at the same time floral buds, open flowers, senescent flowers and smaller fruits; thus, the period of sprouting of the first buds and the falls of the last styles extends for about two months in the same plant. The same period is about 40 days, when it comes to the same bud (Ducroquet \& Hickel, 1991).
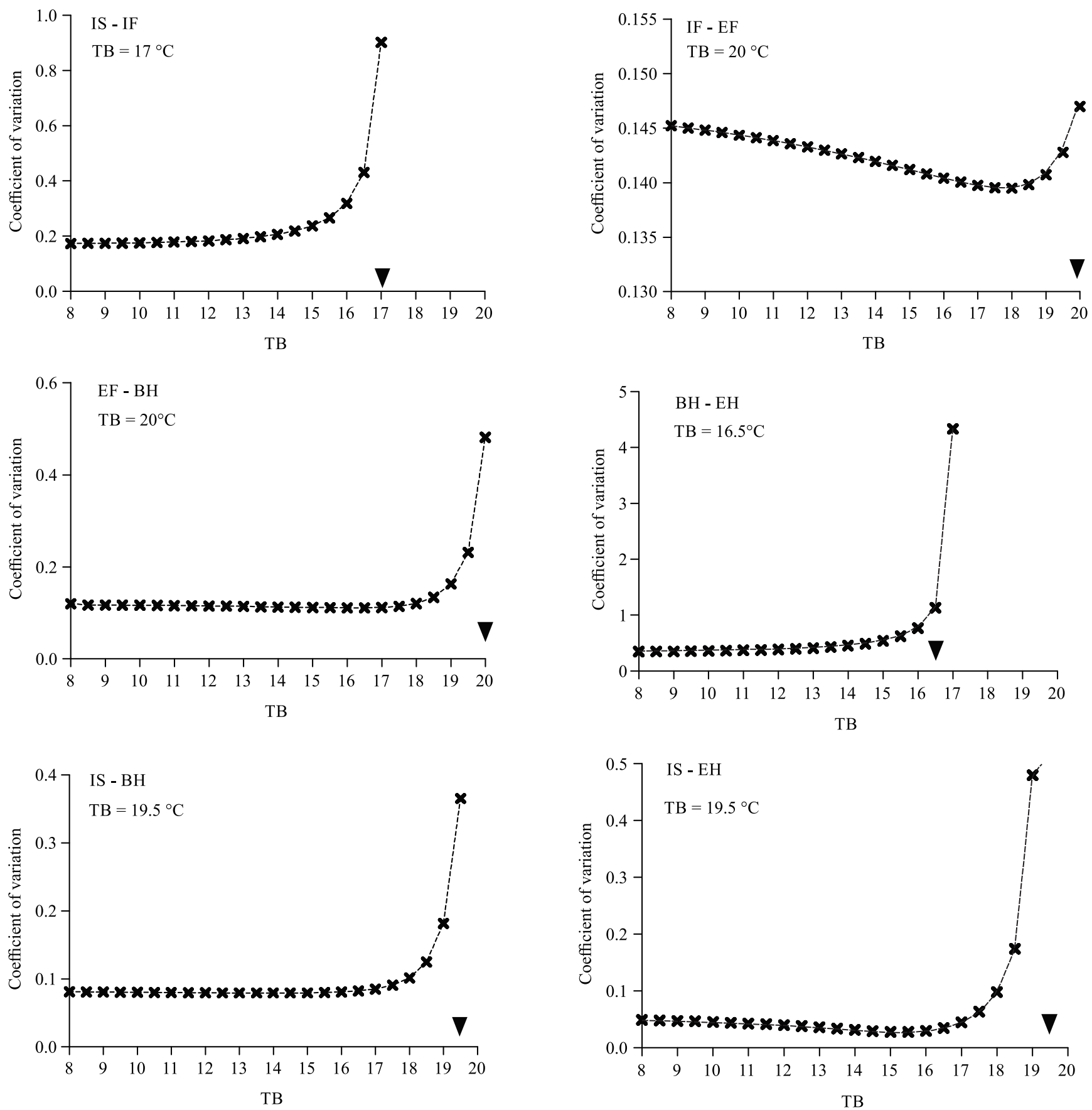

Figure 3. Maximum base temperature (TB) of six phenological stages of feijoa (Acca sellowiana) accessions by the method of lower variability (Arnold, 1959): A, from initial sprouting (IS) to initial flowering (IF); B, from IF to the end of flowering (EF); $\mathrm{C}$, from $\mathrm{EF}$ to the beginning of harvest $(\mathrm{BH})$; $\mathrm{D}$, from $\mathrm{BH}$ to the end of harvest (EH); $\mathrm{E}$, from IS to $\mathrm{BH}$; and $\mathrm{F}$, from IS to EH. The accessions are maintained by the Active Germplasm Bank, in the municipality of São Joaquim, in the state of Santa Catarina, Brazil. Arrows point to TB value. 
On average, 176 days (ranging from 130 to 227 days) were necessary for all accessions to develop from the initial sprouting to the harvest, while the estimated $\mathrm{Tb}$ and TB from sprouting to harvest were 10.6 and $19.5^{\circ} \mathrm{C}$, respectively (Table 1). As in most feijoa genotypes, fruit ripe from March through May, the development and plantings of cultivars of different cycles facilitate the management, harvesting, and marketing. Fruit marketing is a very important issue because feijoa fruit show a short postharvest life due to the occurrence of physicochemical changes (Amarante et al., 2017).

In Colombia (department of Cundinamarca), the development of fruit from flower bud to harvest takes from 120 to 150 days, depending on the cultivar and the planting site (Quintero Castillo, 2003). ParraCoronado et al. (2015a), also in Colombia, evaluated the phenology of the Quimba cultivar, in two localities with different altitudes, and they found that feijoa needs on average $167.5 \pm 4.97$ days, in the locality of San Francisco (at 1,800 m altitude), and 210.25 \pm 10.08 days, in the locality of Tenjo (at 2,580 m altitude), for its development from sprouting to the harvest; these authors observed that the fruit produced at higher temperatures $\left(18^{\circ} \mathrm{C}\right.$, in San Francisco) grew and developed faster and required fewer calendar days from anthesis to harvest.

From initial sprouting to flowering, the AGB accessions of feijoa required, on average, 209.1 GDD, and the amplitude ranged from 96 to 376.08 GDD, since from initial until the end, the flowering demanded on average $230.4 \mathrm{GDD}$, and values ranged from 95.2 to 515.8 GDD. From the end of flowering to the beginning of harvest, feijoa accessions took 575.7 GDD, with values varying from 402.7 to 828.5 GDD, and from the beginning to the end of harvest they took 153.7 GDD, with values ranging from 17.5 to 364.9 GDD (Table 2). From sprouting to harvest, feijoa plants required 1,014.4 GDD, ranging from 821.7 to $1,252.4$ GDD. In all phenological stages, variations of degreeday were found between the accessions, which may be related to their phenological characteristics.

Parra-Coronado et al. (2016) evaluated the equivalence between days post-anthesis (DAA) and thermal time or degree-days of growth for feijoa in two different areas; these authors found that in orchards with higher altitudes, more days were needed from anthesis to harvest, in comparison to cultivated areas at lower altitudes. However, less GDD is needed because they depend directly on the temperatures measured at each location.

The thermal time found in the feijoa accessions, in the AGB-Feijoa, are lower than those observed by Parra-Coronado et al. (2015b) to produce a mature fruit of feijoa, in Colombia, where the base temperature is $1.74^{\circ} \mathrm{C}$, and plants need 2,651 GDD from the sprouting to harvest. This result is probably due to the variations of the different climatic conditions where feijoa was produced.

As expected, the influence of environmental factors plays an important role in A. sellowiana phenology. However, during growth and development, the weather conditions (temperature, rainfall, relative humidity, and radiation), altitude and degree-days of growth have the greatest influence on the physicochemical characteristics of feijoa fruit (Parra-Coronado et al., 2015a, 2017; Ramírez \& Kallarackal, 2018).

Both $\mathrm{Tb}$ and GDD estimated for feijoa in the present study are lower than those estimated for grapevine cultivated in the same subtropical conditions. Using the $\mathrm{Tb}$ of $10^{\circ} \mathrm{C}$, the thermal time requirements of grape cultivars produced in the South of Brazil were 1,260.9 GDD for Isabel (Sato et al., 2008), and 1,375.5 GDD for Tannat (Santos et al., 2007).

At the beginning of the harvest, three groups of accessions were formed, based on the harvest time of the Brazilian commercial cultivars. The AGB-Feijoa accessions were well-discriminated, with $23.7 \%$ early, $47.8 \%$ intermediary, and $28.5 \%$ late ripening (Figure 1). Based on $\mathrm{Tb}=10.6^{\circ} \mathrm{C}$ and $\mathrm{TB}=19.5^{\circ} \mathrm{C}$, the early accessions for the maturity $(n=15)$ required $913.4 \pm 12.3$ GDD to reach the harvest from the sprouting; the intermediary accessions $(\mathrm{n}=17)$ required 1002.0 \pm 17.4 GDD; and the late accessions $(n=17)$ required 1092.8 \pm 12.9 GDD (Table 2). With five accessions by group, from sprouting to harvest, the early accessions required 201 days and 918.4 GDD, intermediary accessions required 205 days and 1,011.8 GDD, and late accessions, 226 days and 1,090.0 GDD (Table 2, Figure 4). These results show that there is variability in the phenology of feijoa, since distinct accessions require different amount of days and thermal time to reach the harvest.

The thermal time strategy is widely used in crop management. According to Santos et al. (2007), the knowledge of GDD allows of a better planning of agricultural activities, such as better distribution of 


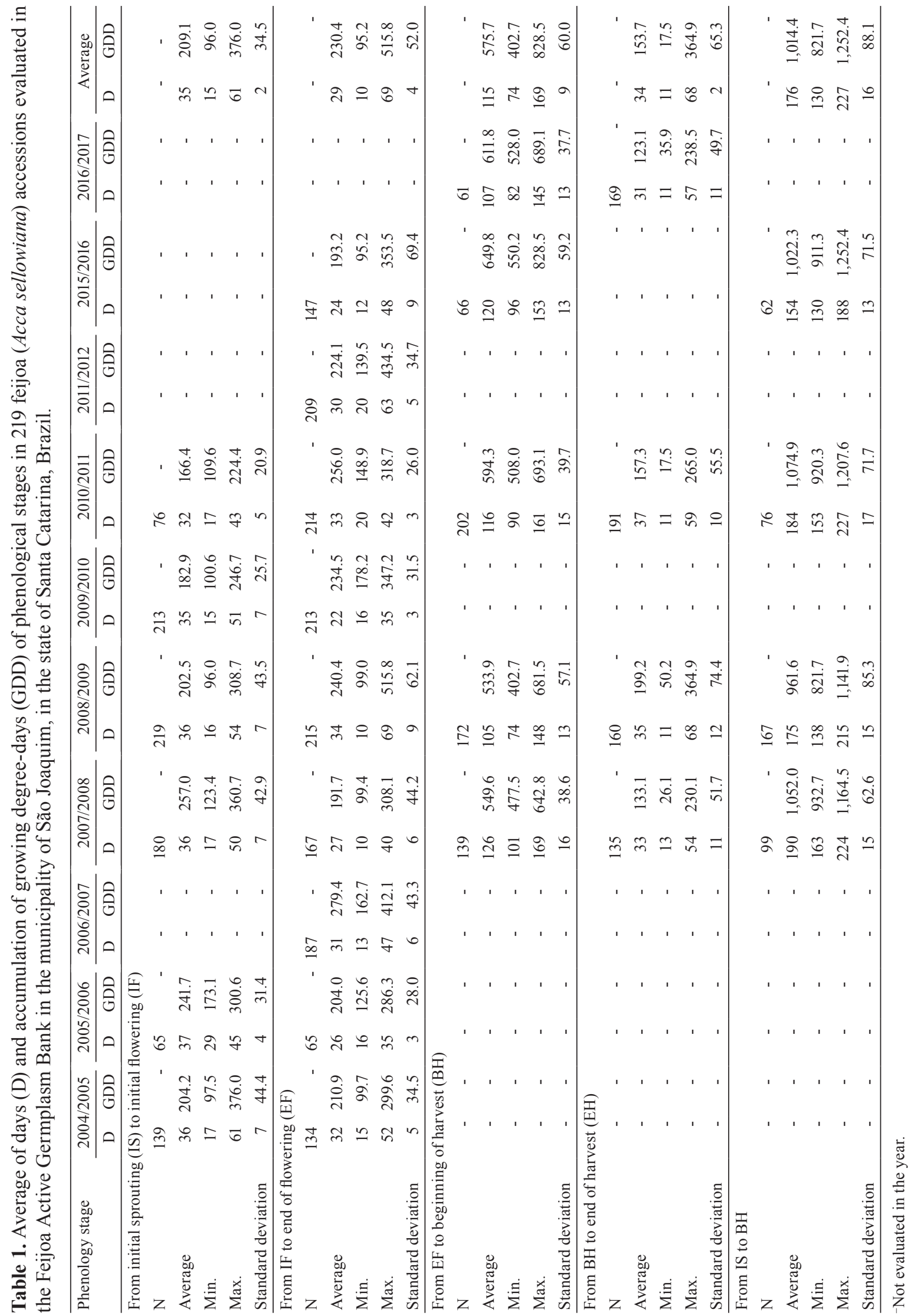




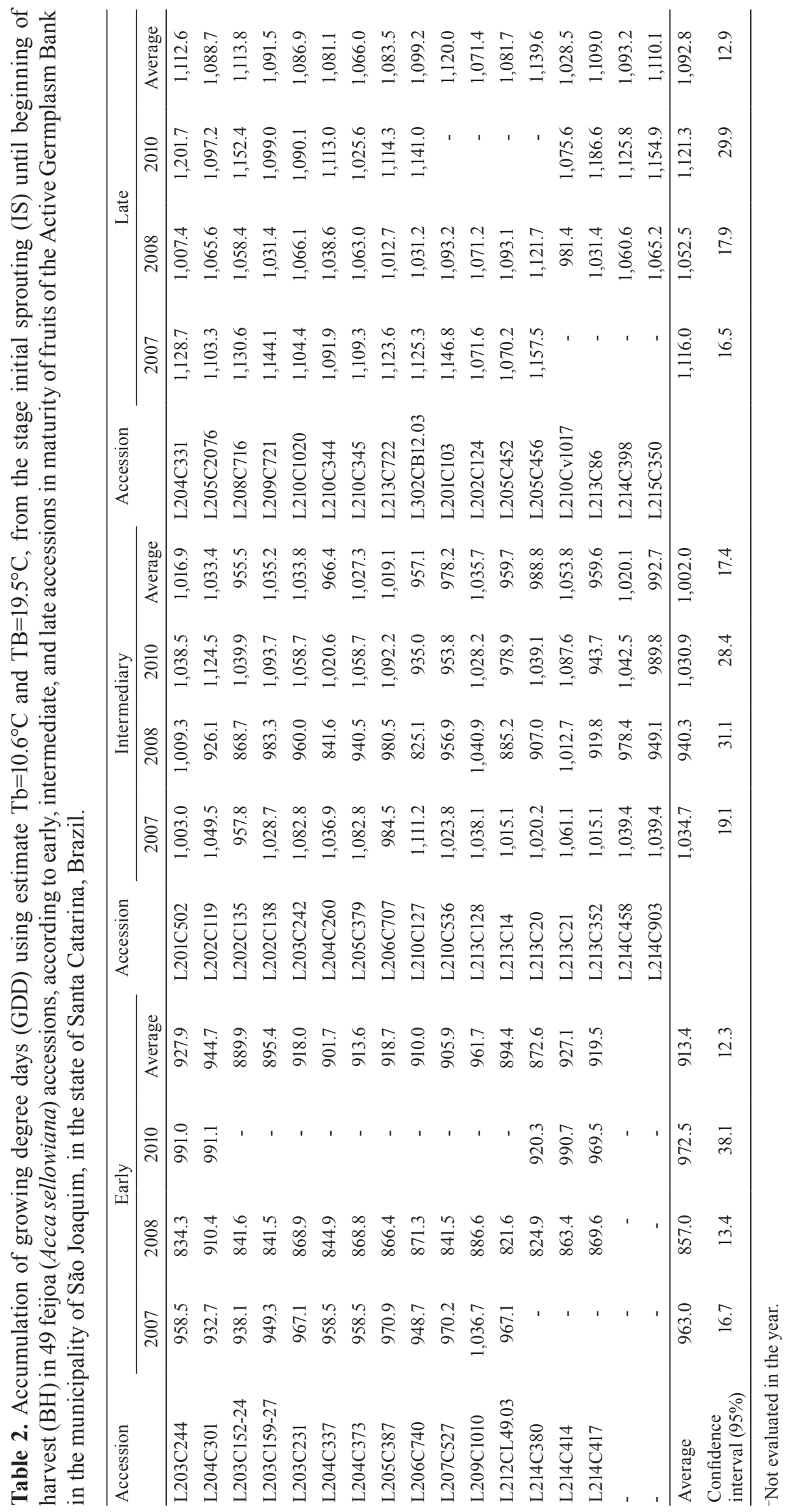




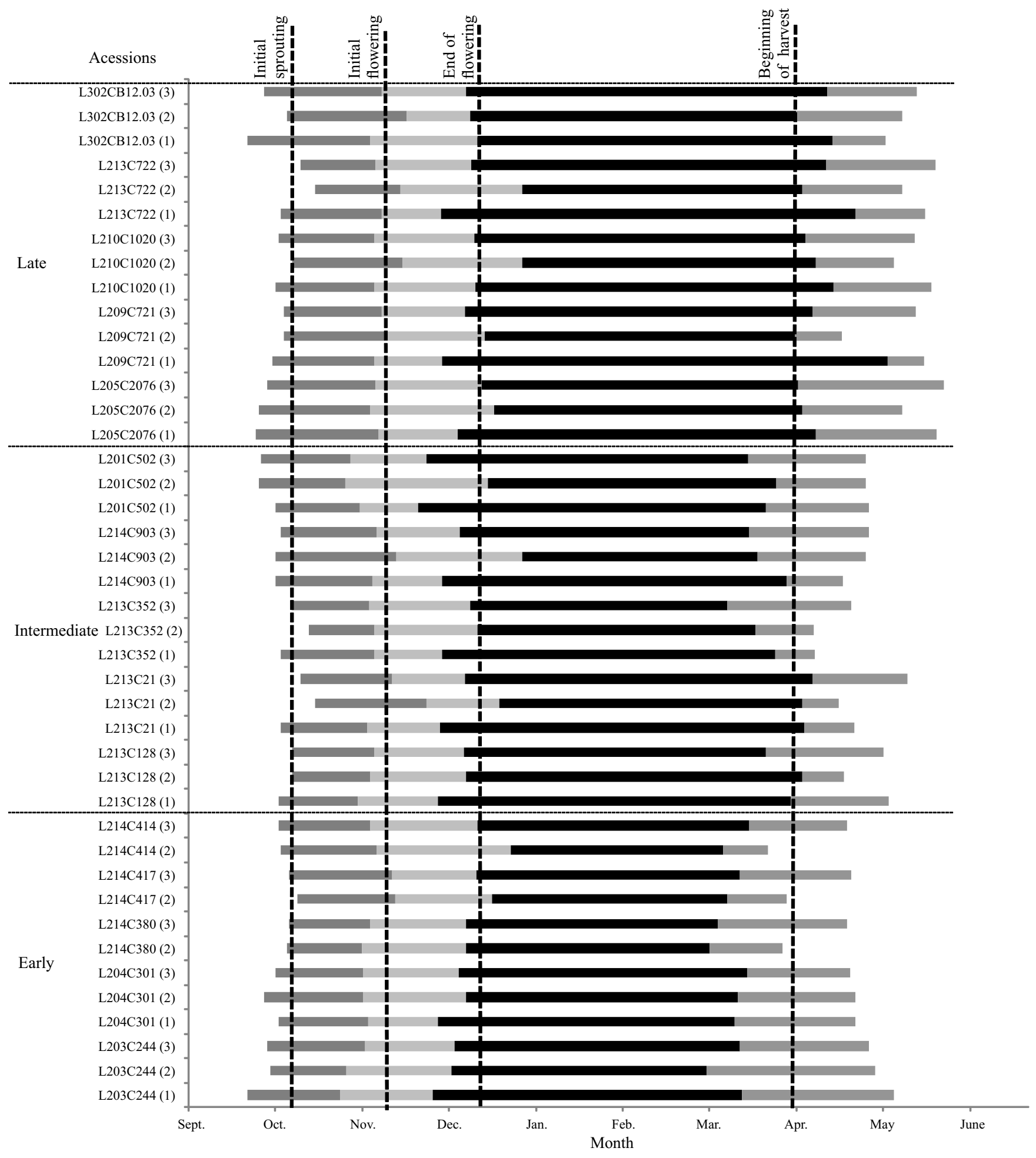

Figure 4. Development (days) of 15 accessions of feijoa (Acca sellowiana) from initial sprouting until the end of the harvest, classified for fruit maturity as early, intermediary, and late. In parentheses is the crop season: (1) 2007/2008, (2) 2008/2009, and (3) 2010/2011. The vertical lines indicate the average (days) of each phenological stages. Maintained by the Feijoa Active Germplasm Bank, in the municipality of São Joaquim, in the state of Santa Catarina, Brazil. 
labor in the most adequate periods, such as harvesting. The thermal time strategy also makes it possible to know the thermal requirements of different crops, which can be used to differentiate them between early and late genotypes (Sato et al., 2008; Salazar-Gutierrez et al., 2013). It is also very important to have cultivars with fruit harvesting at different times, as this facilitates the labor and the scheduling of fruit delivery. Therefore, the growing degree-day determination of feijoa phenological stages, especially for the sprouting and harvesting stages, would be a valuable selection criterion in breeding programs.

\section{Conclusions}

1. The sprouting of the 247 accessions of feijoa (Acca sellowiana) from the Active Germplasm Bank (AGB-Feijoa) begins in the middle of September, extending until the end of October; and the flowering of feijoa begins in the end of October, but it is concentrated in the end of November.

2. The phenological cycle of 167 feijoa accessions, from the initial sprouting to fruit maturation occurs in 176 days on average, and may vary between the accessions (from 130 to 227 days); and early, intermediate, and late accessions provide fruit production from March through late May.

3. The temperature values of $\mathrm{Tb}=7.76^{\circ} \mathrm{C}$ and $\mathrm{TB}=17^{\circ} \mathrm{C}$ are necessary when feijoa plants start to sprout, just after winter, and from sprouting until the beginning of harvest, when the calculated values are $10.6^{\circ} \mathrm{C}$ for $\mathrm{Tb}$ and $19.5^{\circ} \mathrm{C}$ for $\mathrm{TB}$; on average, the feijoa accessions require 1,014.4 GDD to complete their productive cycle; the thermal requirements show differences for early, intermediate, and late accessions to reach fruit ripening.

4. The existing diversity in the fruit development cycle of AGB-Feijoa accessions allows of the development of early, intermediate, and late cultivars, which favors the management, as well as allows for the regular supply of feijoa fruit to the market for a longer time.

\section{Acknowledgments}

ToConselho NacionaldeDesenvolvimentoCientífico e Tecnológico (CNPq), for financial resources (project no. 478270/2012-7), and for scholarships for the second and last author; to Fundação de Amparo à Pesquisa do Estado de Santa Catarina (Fapesc), for financial support (project no. 5288/2011-4 and 2780/2012-4); to Coordenação de Aperfeiçoamento de Pessoal de Nível Superior (Capes, finance code 001), for financial support to the research; and to Secretaria Nacional de Educación Superior, Ciencia, Tecnología e Innovación (Senescyt, Ecuador).

\section{References}

AMARANTE, C.V.T. do; SOUZA, A.G. de; BENINCÁ, T.D.T.; STEFFENS, C.A. Fruit quality of Brazilian genotypes of feijoa at harvest and after storage. Pesquisa Agropecuária Brasileira, v.52, p.734-742, 2017. DOI: https://doi.org/10.1590/s0100$204 \times 2017000900005$.

ARNOLD, C.Y. The determination and significance of the base temperature in a linear heat unit system. Proceedings of the American Society for Horticultural Science, v.74, p.430-445, 1959 .

BRUNINI, O.; LISBÃO, R.S.; BERNARDI, J.B.; FORNASIER, J.B.; PEDRO JÚNIOR, M.J. Temperatura-base para alface cultivar "White Boston", em um sistema de unidades térmicas. Bragantia, v.35, p.213-219, 1976. DOI: https://doi.org/10.1590/ s0006-87051976000100019.

CAMPAGNOLO, M.A.; PIO, R.; DALASTRA, I.M.; CHAGAS, E.A.; GUIMARÃES, V.F.; DALASTRA, G.M. Sistema desponte na produção de figos verdes "Roxo de Valinhos". Ciencia Rural, v.40, p.25-29, 2010. DOI: https://doi.org/10.1590/s010384782009005000219 .

CHAVES, B.; SALAZAR, M.R.; SCHMIDT, T.; DASGUPTA, N.; HOOGENBOOM, G. Modeling fruit growth of apple. Acta Horticulturae, v.1160, p.335-340, 2017. DOI: https://doi.org/10.17660/ActaHortic.2017.1160.48.

CIRAM. Centro de Informações de Recursos Ambientais e de Hidrometeorologia de Santa Catarina. Available at: $<\mathrm{http}$ :/ ciram.epagri.sc.gov.br/>. Accessed on: Sept. 302020.

DUCROQUET, J.-P.H.J.; HICKEL, E.R. Fenologia da goiabeira serrana (Feijoa sellowiana, Berg) no Alto Vale do Rio do Peixe, Santa Catarina. Revista Brasileira de Fruticultura, v.13, p.313320, 1991.

DUCROQUET, J.P.H.J.; HICKEL, E.R.; NODARI, R.O. Goiabeira serrana (Feijoa sellowiana). Jaboticabal: Funep, 2000. 66p. (Série Frutas nativas, 5).

DUCROQUET, J.P.H.J.; NUNES, E. da C.; GUERRA, M.P.; NODARI, R.O. Novas cultivares brasileiras de goiabeira-serrana: SCS 414-Mattos e SCS 415-Nonante. Agropecuária Catarinense, v.21, p.79-82, 2008.

DUCROQUET, J.P.H.J.; RIBEIRO, P.A. Goiabeira serrana: fatores climáticos trazem a pesquisa de volta ao centro de origem da espécie. Agropecuária Catarinense, v.9, p.13-15, 1996.

DUCROQUET, J.-P.H.J.; SANTOS, K.L. dos; ANDRADE, E.R. de; BONETI, J.I. da S.; BONIN, V.; NODARI, R.O. As primeiras 
cultivares brasileiras de goiabeira serrana: SCS 411 Alcântara e SCS 412 Helena. Agropecuária Catarinense, v.20, p.77-80, 2007.

LOPES, P.R.C.; OLIVEIRA, I.V. de M.; SILVA-MATOS, R.R.S. da; CAVALCANTE, I.H.L. Caracterização fenológica, frutificação efetiva e produção de maçãs 'Eva' em clima semiárido no Nordeste brasileiro. Revista Brasileira de Fruticultura, v.34, p.1277-1283, 2012. DOI: https://doi.org/10.1590/S010029452012000400038.

MIRANDA, M.N.; CAMPELO JÚNIOR, J.H. Soma térmica para o subperíodo semeadura-maturação de feijão cv. carioca em Colorado do Oeste, Rondônia. Pesquisa Agropecuaria Tropical, v.40, p.180-185, 2010. DOI: https://doi.org/10.5216/pat.v40i2.6790.

OMETTO, J.C. Bioclimatologia vegetal. São Paulo: Agronômica Ceres, 1981. 425p.

PARRA-CORONADO, A.; FISCHER, G.; CAMACHOTAMAYO, J.H. Development and quality of pineapple guava fruit in two locations with different altitudes in Cundinamarca, Colombia. Bragantia, v.74, p.359-366, 2015a. DOI: https://doi.org/10.1590/1678-4499.0459.

PARRA-CORONADO, A.; FISCHER, G.; CAMACHOTAMAYO, J.H. Growth model of the pineapple guava fruit as a function of thermal time and altitude. Ingeniería e Investigación, v.36, p.6-14, 2016. DOI: https://doi.org/10.15446/ing.investig. v36n3.52336.

PARRA-CORONADO, A.; FISCHER, G.; CAMACHOTAMAYO, J.H. Model of pre-harvest quality of pineapple guava fruits (Acca sellowiana (O. Berg) Burret) as a function of weather conditions of the crops. Bragantia, v.76, p.177-186, 2017. DOI: https://doi.org/10.1590/1678-4499.652.

PARRA-CORONADO, A.; FISCHER, G.; CHAVESCORDOBA, B. Tiempo térmico para estados fenológicos reproductivos de la feijoa (Acca sellowiana (O. Berg) Burret). Acta Biológica Colombiana, v.20, p.163-173, 2015b. DOI: https://doi.org/10.15446/abc.v20n1.43390.

PEZZOPANE, J.R.M.; PEDRO JÚNIOR, M.J.; CAMARGO, M.B.P. de; FAZUOLI, L.C. Exigência térmica do café arábica cv. Mundo Novo no subperíodo florescimento-colheita. Ciência e Agrotecnologia, v.32, p.1781-1786, 2008. DOI: https://doi.org/10.1590/S1413-70542008000600016.

QUINTERO CASTILLO, C. Selección de cultivares, manejo del cultivo y regulación de cosechas de feijoa. In: FISCHER, G.; MIRANDA LASPRILLA, D.; CAYÓN SALINAS, G.; MAZORRA AGUDELO, M. (Ed.). Cultivo, poscosecha y exportación de la feijoa (Acca sellowiana Berg). [Bogotá]: Universidad Nacional de Colombia: Produmedios, 2003. p.49-71.
R CORE TEAM. R: a language and environment for statistical computing. 2017. Available at: <https://www.r-project.org/>. Accessed on: Apr. 112017.

RAMÍREZ, F.; KALLARACKAL, J. Phenological growth stages of feijoa [Acca sellowiana (O. Berg) Burret] according to the $\mathrm{BBCH}$ scale under tropical Andean conditions. Scientia Horticulturae, v.232, p.184-190, 2018. DOI: https://doi.org/10.1016/j.scienta.2017.12.059.

SAIFERT, L.; SÁNCHEZ-MORA， F.D.; BORSUK, L.J.; DONAZZOLO, J.; COSTA, N.C.F. da; RIBEIRO, H.N.; NODARI, R.O. Evaluation of the genetic diversity in the feijoa accessions maintained at Santa Catarina, Brazil. Crop Science, v.60, p.345356, 2020. DOI: https://doi.org/10.1002/csc2.20088.

SALAZAR-GUTIERREZ, M.R.; JOHNSON, J.; CHAVESCORDOBA, B.; HOOGENBOOM G. Relationship of base temperature to development of winter wheat. International Journal of Plant Production, v.7, p.741-762, 2013. DOI: https://doi.org/10.22069/IJPP.2013.1267.

SÁNCHEZ-MORA， F.D.; SAIFERT, L.; CIOTTA, M.N.; RIBEIRO, H.N.; PETRY, V.S.; ROJAS-MOLINA, A.M.; LOPES, M.E.; LOMBARDI, G.G.; SANTOS, K.L. dos; DUCROQUET, J.P.H.J.; NODARI, R.O. Characterization of phenotypic diversity of feijoa fruits of germplasm accessions in Brazil. Agrosystems, Geosciences \& Environment, v.2, p.1-11, 2019. DOI: https://doi.org/10.2134/age2019.01.0005.

SANTOS, C.E. dos; ROBERTO, S.R.; SATO, A.J.; JUBILEU, B. da S. Caracterização da fenologia e da demanda térmica das videiras 'Cabernet Sauvignon' e 'Tannat' para a região norte do Paraná. Acta Scientiarum. Agronomy, v.29, p.361-366, 2007. DOI: https://doi.org/10.4025/actasciagron.v29i3.288.

SATO, A.J.; SILVA, B.J. da; SANTOS, C.E. dos; BERTOLUCCI, R.; SANTOS, R. dos; CARIELO, M.; GUIRAUD, M.C.; FONSECA, I.C. de B.; ROBERTO, S.R. Fenologia e demanda térmica das videiras 'Isabel' e 'Rubea' sobre diferentes portaenxertos na região norte do Paraná. Semina: Ciências Agrárias, v.29, p.283-292, 2008. DOI: https://doi.org/10.5433/1679$0359.2008 v 29 \mathrm{n} 2 \mathrm{p} 283$.

SEGANTINI, D.M.; LEONEL, S.; CUNHA, A.R. da; FERAZ, R.A.; RIPARDO, A.K. da S. Exigência térmica e produtividade da amoreira-preta em função das épocas de poda. Revista Brasileira de Fruticultura, v.36, p.568-575, 2014. DOI: https://doi.org/10.1590/0100-2945-295/13.

SEGANTINI, D.M.; TORRES, L.M.; BOLIANI, A.C.; LEONEL, S. Fenologia da figueira-da-índia em Selvíria-MS. Revista Brasileira de Fruticultura, v.32, p.630-636, 2010. DOI: https://oi.org/10.1590/S0100-29452010005000049. 